\title{
$\mathrm{A} 1$ の鑄 造に關する研究(第2 報) 再び Casting Crackにつルて
}

池 野 佾 志*

Takashi Ikeno : Investigation on Casting of Aluminium (II). On Casting Cracks (Continued) . The effect of $\mathrm{Mn}$ or $\mathrm{Cu}$ present in the melt upon the development of cracks was investigated by measuring the shrinkage or the cracks which appeared upon casting aluminium in the same metal moulds used in the experiment reported previously. The following results were obtained: There is a relationship of casting and mould temperature within a limited range which favors prevention of cracking, varying according to the kind and the content of the impurities. The shrinkage of the $\mathrm{Al}$ ingot increases with the rise in $\mathrm{Cu}$ contens, so that opportunities for cracking are multiplied. but the effect of $\mathrm{Cu}$ is much smaller than that of $\mathrm{Si}$ On the other hand, the shrinkage scarcely increases with the rise in Mn content. In this experiment, the cause of cracking was assumed, in a general way, to lie in the stress due to the disparity of the solidification range of the alloy, but in practical operation, the tendency to cracking is to a marked degree affected by other factors for example, the casting technique.

(Received January 17,1953)

\section{I. 緒高}

賈に報告した $\mathrm{Fe}$ 扣よび $\mathrm{Si}$ の擧動に引續いて，普通作 業時不純物として混入して來る可能性のある $\mathrm{Cu}$ 扣よび Mn を99.61\%(Fe 09.18, Si 0.20 および Cu $0.01 \%)$ の工業用純 Al に添加し, 前報(1) と同樣の方法によつて鑄 割れ傾向を追求した・さらにこれら諸實驗に扎いて得られ た結果を攄張して，實際の鑄塊割れ現象に對して二三の考 祭を試みた。

\section{II. 寞 驗 結 果}

本實驗に使用した金型および實驗方沠については前報告 の場合と全く同樣であるので省略する.

\section{Cu の 影}

䥂込溫度を $710^{\circ}$ 一定として金型溫度に對する收縮信の 背化を調べた結果が Fig.1〜2である. Cu を 0.2〜1.0 \%涯加した場合にも，長さ方向における收縮率 $\alpha_{l}$ は金型

* 北陸輕金屬工業株式會斻技術課

(1) 著者，1953 年 4 月本會東京大會に發表.
溫度に對して Fe あるいは $\mathrm{Si}$ を添加した場合と同様の槳 化をするが，それらの值は全般に可成り高く收縮割れを助

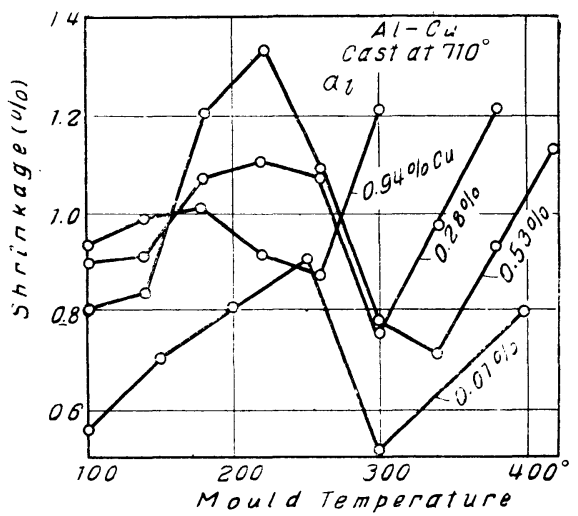

Fig. 1 Effect of $\mathrm{Cu}$ Upon Shrinkage $\alpha_{l}$. 長する傾向を示している. 極小の谷の值は 0.2〜0.5\%の 添加範間で著しい變化はないが，金型溫度は高溫にずれ 1 \%になると逆に低溫側に移行する. 值俓方向における收樎 率 $\boldsymbol{c}_{i l}$ は長さ方问 $a i$ の極小の谷に相掌する位置で極大 となり、それらの傾向もまた Fe あるいは Si 添加の場合 
と大體同様である. 以上の變化を癙めて $\mathrm{Cu}$ 量と對應して 調べてみると $\mathrm{Cu}$ 0.2〜 1.0\% 添加によつて收縮率はほぼ

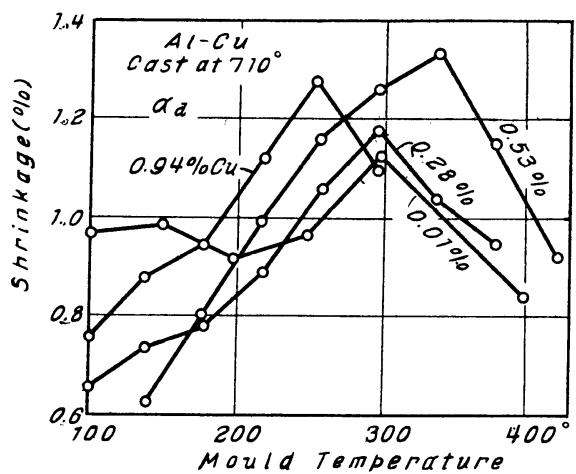

Fig. 2 Effect of $\mathrm{Cu}$ Upon Shrinkage $\alpha_{d}$.

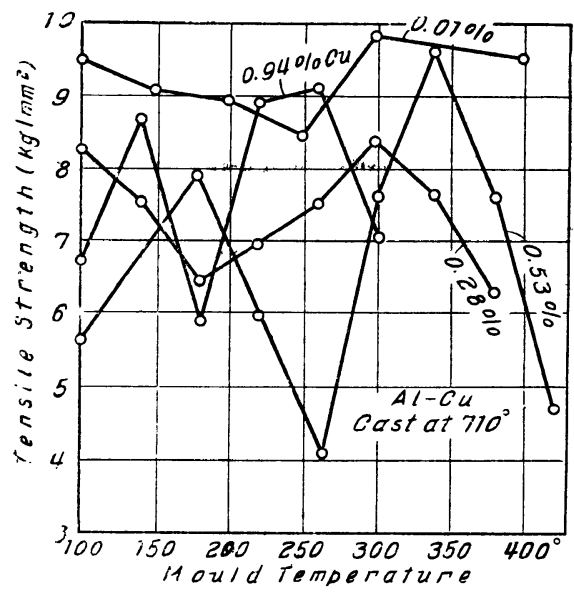

Fig. 3 Effect of $\mathrm{Cu}$ Upon Tensile Strength.

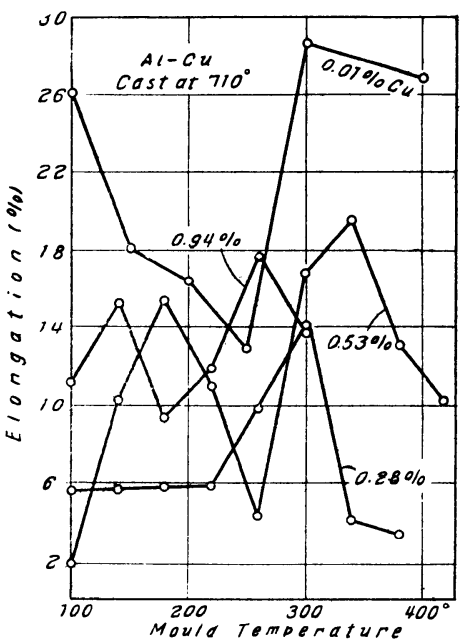

Fig. 4 Effect of $\mathrm{Cu}$ Upon Elongation.

同程度の

增加を示

し, これ らの間に は著しい 差はない ようであ る. ただ しその影 響は Al$\mathrm{Si}$ 柔の場 合ほど顯 著でな い. 更に 收縮率試 驗後の試 料につい て見掛の 抗唇力捛 よび伸の 變化を測

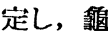
裂弡生の 程度を比 較すると Fig. 3 4 のよら になる。

高純度のものの 鶂裂は微細で抗 㲀力の低下は者 しくない. Cuを 添加すると金型 溫度の適當範稖 を外れると轁裂 は著しく大きく なり, 特に $\mathrm{Cu}$ $0.5 \%$ 添加のb のでは中央部分 で瑟の約牛分以 上すでに破斷し ているよらであ る. 伸の變化,

Fig. 4 を見ると 抗張力の變化と同梯の傾向を示しているが，その值は全般 的に著しく低いままた引張試驗後における切断筒所を見る と,99.61\%のもの〉金整盜度に對する算化に比べて, $\mathrm{Cu}$

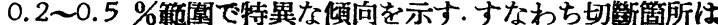
ほとんど中央部分はより下方に多く，99.61\%が中央より 上方に集中的に發生しているのに反して全く對蹠的であ る. $\mathrm{Cu}$ 量が多く $1 \%$ にもなると却つて高純度のもの小變化 に近似してくる．金型温度が低い場合に外部より觀察され

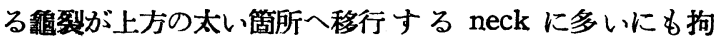

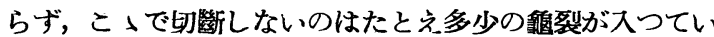
ても、こかが生部分より太いために却て强くなつている ことによつて理解される・また金型溫度が高くなると變裂 が中央部分に發生し，こへで切斷することは $\mathrm{Al}-\mathrm{Si}$ 系と 良く似た現象と考えられる. 以上の變化から，Cu 0.2 $0.5 \%$ の添加は凝固割れを助長すると結論される.

\section{2. $\operatorname{Mn} の$ 影}

Mn を添加して鑄込溫度 $710^{\circ}$ 一定として，收縮率を測 定した結果が Fig.5〜6 である. Mn 0.24\%程度では

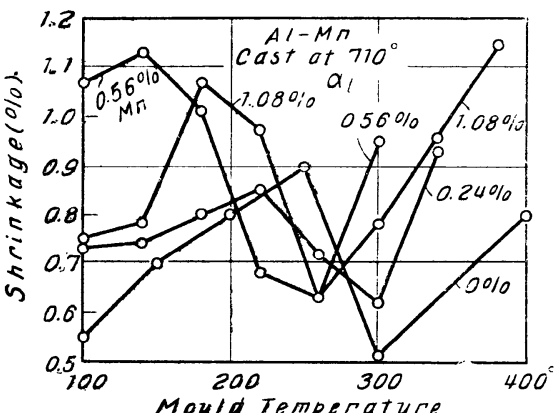
Shrinkage $\alpha_{l}$.
Fig. 5 Effect of Mn Upon ๙ び $\boldsymbol{\alpha}$ に 餘り大き い變化は ないよう である が, 多少 收縮害割れ に對して 不利な傾 间を示し

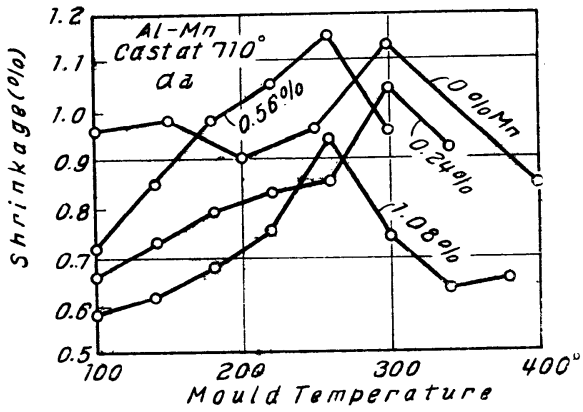

Fig. 6 Effect of Mn Upon Shrinkage $a$ at. ている．ただし實驗誤差を考慮に入れると，ほとんど影䪪 を與えないといつて良いであろらか. しかるに Mn 0.5 $1.0 \%$ になると最適金型温度は低溫側へ移行し，全體とし ての變化の度合も大きくなるこれらの變化を總括して Mn 量と對比して考察してみると に拈ける極小の谷の 值は Mn が增加するほど大さくなる傾向を示しているが, $\mathrm{Cu}$ の場合ほど著しくない.しかし平均值は Mn 0.5\%

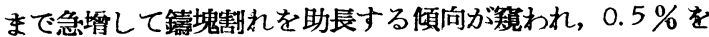
越すと再び減少している. 以上の試料について引张試驗を

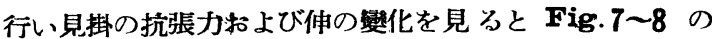
よらになり，その變化は $99.61 \%$ \%のに比べて可成り 大きいが $\mathrm{Cu}$ 添加の場合ほどのことはない. 發生する酸 
裂は $99.61 \%$ に比して大き目で，鑄塊割わ、心對して好ま しい添加元素ではないが，しかし Cu あるいは Si の場合

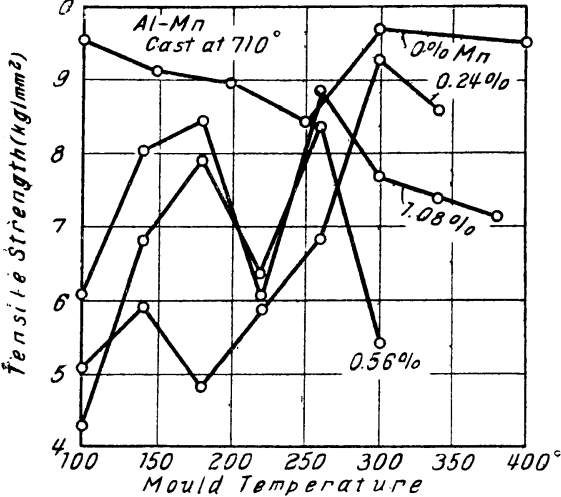

Fig. 7 Effect of Mn Upon Tensile Strength.

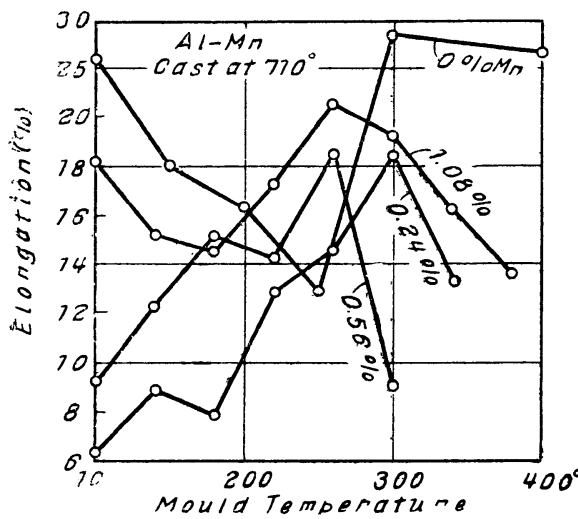

Fig 8 Effect of Mn Upon Elongation.
に比べる とその影 響は遥か に僅少で 岕る・金 型溫度 $200^{\circ}$ 以下 の切断简 所は䲼裂 發牛简所 ではな <, 中央 部分より 下方寄り に切断L ている.

抗張力 2 段目の極 大を越え ると龜裂 發生筒所 と切斷簡 所とが大 體一致し ていて, 金型溫度 が高い場合にも中央附近に鼠裂が入つて挔らず，その傾向 はもしろ Fe 添加の場合に似ている.

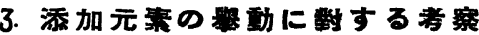

普通作業時に混入する機會の最む多い $\mathrm{Fe}, \mathrm{Si}, \mathrm{Cu}$ 呿よ

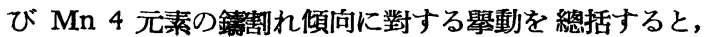
鑄制れ傾问を抑制するものは Fe のみで $\mathrm{Si}$ および Cu は 助長する. ことに Si の作用は顯著でそれに比べると $\mathrm{Cu}$ は可成り緩徐であるといえる. Mn は幾分助長する傾向に あるが，前二者に比較すると著しく微弱でまず影響を與え ないと考えても良い程度である. 以上 4元素について $\mathrm{Al}$ 側平衡狀熊國(2)を調べてみると，Fig.9のよらになり，

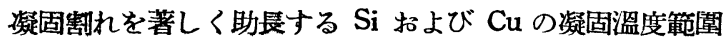
は極めて廣く，特に Si は飛拢けている. また比較的凝固 割れに對して影響を與えない Mn および却つて 扣制する 傾向のある Fe の凝固溫度區域は極めて狹い. 夯に本實 驗に使用した $\mathrm{Al}-\mathrm{Cu}$ 括よび $\mathrm{Al}-\mathrm{Mn}$ 系列の試料について 熱分析を行い，Fig.10の結果を得た.この Cu拈よび Mn を添加した場合の凝固開始括よび終了溫度を Fig. 9 の狀態國の中に記入してみると、凝固㴧度範圍の長さが $\mathrm{Fe}, \mathrm{Mn}, \mathrm{Cu}$ 抢よび $\mathrm{Si}$ の順になつていて $\mathrm{Al}-\mathrm{Cu}$ 系ではほ

（2）金序便覧より引用した.

とんど差巽はないが，Mn 添加の場合には從來の Al-Mn 禾狀熊圖とは可成り相違している. Al-Mn に Siが 0.15

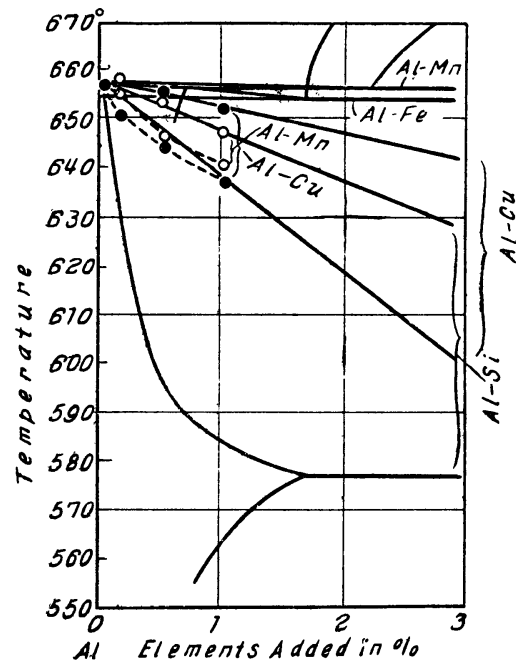

Fig. 9 Equilibrium Diagrams.
〜 $0.16 \%$ 共 存している と，共晶溫度 が $640^{\circ}$ に低 下寸るとい5 事實(3)がある ことからその 差哄は $\mathrm{Si}$ 共 存の影響によ るものと解し たい. 更に金 型溫度に對す る見掛けの抗 韭力變化の模 樣を見ると， Mn 添加の場

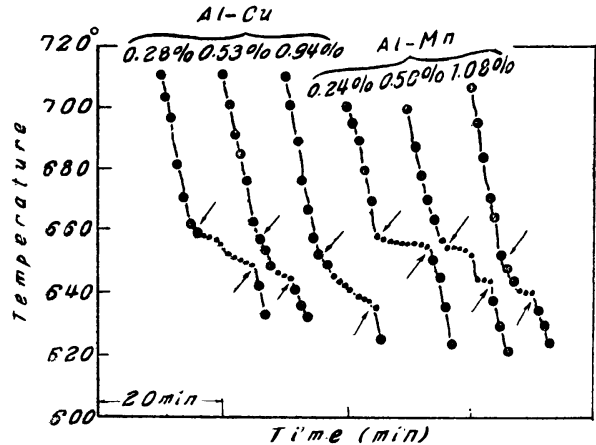

Fig. 10 Cooling Curves at Thermal Analysis.
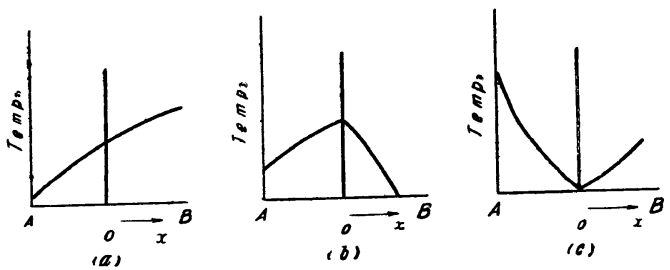

Fig. 11 Temperature Inclination in Longitudinal Derection of Slabs.

合には $99.61 \%$ ののと同じく抗張力變化の極大前に柾 小の谷力゙現われていて大體同樣の經過を示しているにも拘 らず, Fe を添加した場合には極大の山があるばかりで極 小の谷は發生していない. 從つて伸にもその相違が現われ ている. 更に Fe は收縮率を減少させ，Mn はその程度は 微弱であるが却つて增加させる.これらの相違は添加元素 固有の影響とも考えられ，晶出狀態の相違すなわち晶出粒 子の分散形態の相違による影響の問題を併せ考える必要が あると思われる.

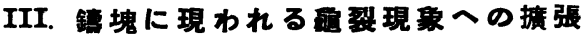

(3) Boshard, Alluminis, 1(1952) 
以上の實驗によつて自由な收縮が妨害された場合に起る

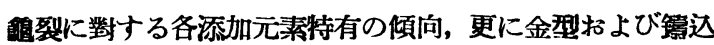
溫度の相對的關係によつて，ある程度收縮割れに對して効 果的な範圍があることも明らかにされた，さて slab 上の 一點 O を中心にして隣接する 2 點 A および B 間に起 り得る潈度勾配には Fig. 11 に示す (a)〜(c) の三通り の場合が考えられる.（a）の場合は普通 layerbylayerに 凝固が進行する理想的凝固過程で龜裂梳入り難い等であ る.（c）は本實驗の場合の凝固過程であるが, 普通の場合 にはこのよ5な温度分布は一寸考えられない（b）は傾倒 式による slab 凝固經過中に最もしばしば起り得る可能性 がある.どんな凝固過程をとるにしても，何處も自由に收 縮ナることが出來れば凝固割れは起らないであろう. 不 均一な收縮が起つたり，自由な收縮が妨げられるよらな場 合に初めて我裂が發生する. その場合の妨げられた收縮に よつて發生する张力と, その溫度において材料が有する强 度との相對的關係によつて, 龨裂が入つたりあるいは入ら なかつたりナるわけである：この意味から金型壁との接觸 摩擦あるいはその他の條件に應じて必然的に㥿力が發生す る確率の大きいのは（b) あるいは（c）のような場合で, 特に（b) の場合には凝固櫫が兩端に先行して生成し, そ の間に摤まれた部分が遲れて凝固することになり，このよ

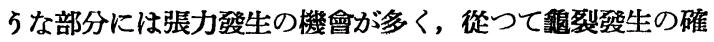
率も大きいことが制る. それらは溫度分布の不均一度が大 きいほど，顯著になるものと思考される．その他溫度分布 の不均一によつて惹起される現象として凝固收縮に對する 收縮孔の生成, 更に收縮孔への熔金補充といら問題も隨伴

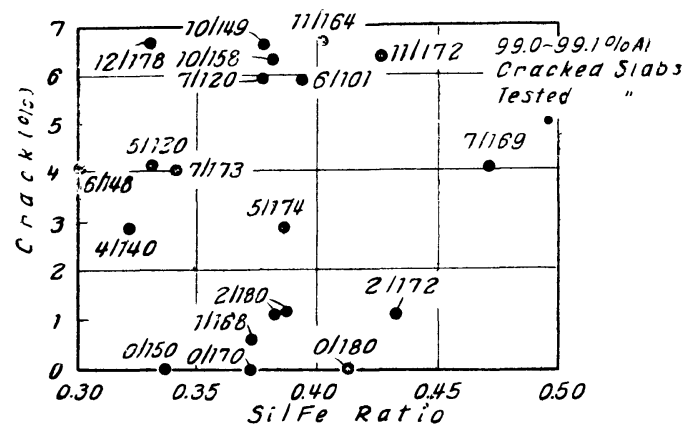

Fig. 12 Relation between the Ratio of $\mathrm{Si} / \mathrm{Fe}$ and Casting Crucks in Practical Casting.

して起り, 龜裂現象への解䆁を谷こ複雜ならしめる可能性

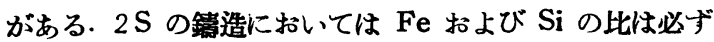
しも一定しない. $\mathrm{Si} / \mathrm{Fe}$ の比と對應して $(\mathrm{Fe}+\mathrm{Si} \doteqdot 0.90$ $\%, \mathrm{Cu}=0.08 \%$ ), 實際の slab 鑄塊に現われる crack の 關係を連續 1 ケ月間の操業結果に照合してみると Fig. 12 のようになり，割れは必ずしも $\mathrm{Si} / \mathrm{Fe}$ 比とは一致しない (總計 3169 枚の slab についての結果).これは成分的な 問題よりも，作業技術の問題が更に大きいことを示すもの
と考えられる.

他方 Photo. 1 に slab 斷面の肉眼組織の一例を示すよ らに，外側に crack が發生していないものでも, 內部の 杜狀晶の附近に引け割れが見出され，これが高溫區延時に

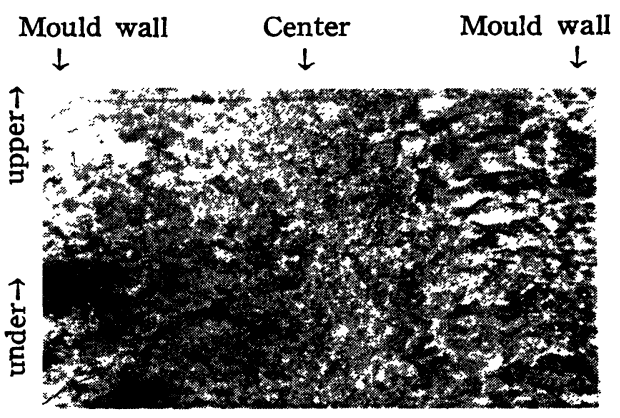

Photo. 1 Macrostructure of Casting Slab at Vertical Direction.

口を開けることもある.これは明らかに凝固收縮の間吵に 對する熔金補充の不足といら問題と關連しており,これら の問題については，實際のものについての詳細な測定が必 要である.ナでにその一部の結果については發表(4)した が，詳細は稿を改めて報告したい。たが本報告においては 鑄塊割れを支配する條件の一つとしての成分的影響を追求 した結果を取扱い，その他の現象については指摘するだけ に止める.

\section{IV. 總括}

（1） Cu は Si ほど著しい影響を與えないが，相當顯著 に收縮割れを助長するよらである、收縮制れに對して有利 な金型溫度は $0.5 \%$ まで高溫側にずれ，それより多量 になると低溫にした方が良い。

(2) Mn は極めて微弱ながら，收䌨割れを助成する傾 向があるが, $\mathrm{Si}$ および $\mathrm{Cu}$ の影響に比較すると，實際問 題として影響を褀えないと考えても良い程度である. 金型 溫度は Mn 量に比例して低溫にした方が良く，Fe の添 加の場合の変化と良く似ている.

(3) $\mathrm{Fe}, \mathrm{Si}, \mathrm{Cu}$ および $\mathrm{Mn}$ の $\mathrm{Al}$ 側二元狀態圆（更に, 實際の熱分析結果）を比較して，收縮嗐丸れを支配するもの は（使用した地金中の $\mathrm{Fe}$ および $\mathrm{Si}$ の存在を考慮すれ ば，3〜 元系として取扱わねばならないが) 凝固温度 範湋が一義的に作用するとして良いと考えた・ただし， Al-Mn 禾については熱分析結果が Al-Mn 禾狀熊圖と一 致しないが，Si O. $15 \%$ 程度の共存によつて,共晶溫度が 低下するといら事實より解䆁した.

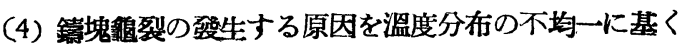
收㴼礁力の發生に求めるべきことを推定し，それが發生す べき㴘度分布の可能性括よび實際作業に颃いては成分的影 㸷だけでなく，その他にも種々の鑄造上の問題があること を示した.

（4）著者, 1952 年 4 月本會東京大會に發表. 